\title{
Dissimilar underwater wet welding of HSLA steels
}

\author{
Jacek Tomków ${ }^{1}$ (D) Dariusz Fydrych ${ }^{1} \cdot$ Grzegorz Rogalski ${ }^{1}$
}

Received: 28 December 2019 / Accepted: 8 June 2020 / Published online: 7 July 2020

(C) The Author(s) 2020

\begin{abstract}
The high-strength low-alloy S460ML and S460N steels were chosen for underwater wet welding of dissimilar T-joints using covered electrodes. For improving the quality of joints, the temper bead welding (TBW) method was used. The application of TBW in pad welding conditions has been investigated earlier but the possibility of usage of this technique in welded joints was not analyzed. The main aim of the study was to check the influence of TBW on the hardness and structures of the heat-affected zone (HAZ) of dissimilar T-joints made in the underwater conditions. The experiments conducted showed that the technique used can reduce the susceptibility to cold cracking by decreasing the hardness in HAZ, which is a result of changes in its structure. The TBW technique reduced the hardness in the HAZ of the S460N steel by 40-50 HV10 and in S460ML by 80-100 HV10. It was also found that the changes in S460ML and $\mathrm{S} 460 \mathrm{~N}$ were much different, and therefore, the investigated technique can provide better results in the steel characterized by lower carbon equivalent $\mathrm{Ce}_{\text {IIW. }}$.
\end{abstract}

Keywords Underwater welding $\cdot$ Wet welding $\cdot$ Cold cracking $\cdot$ Temper bead welding $\cdot$ T-joint $\cdot$ High-strength low-alloy steel

\section{Introduction}

The number of offshore steel constructions is increasing every year. One of the reasons is the oil and gas sources present under the sea, which are being explored more and more. The constructions working in the water environment can be categorized as ships, bridges, wind turbines, terminals, pipelines, and harbor structures such as quay or marginal wharf [1]. In the offshore constructions, damages due to different factors including corrosion, fatigue, and vessel impact, design faults, mechanical damages, and imperfections in welded joints could be found [2-5]. It is very important to predict the location of the damages in the constructions. Most of the methods used for the detection of the damages are based on the numerical and computational approaches and are focused on the localized monitoring of strain $[6,7]$. However, new methods of localization are still developing, for example, a method based on changes in the frequency spectrum [8]. During design processes, offshore structures get their design life, which could often be passed. For example, more than $50 \%$ of

Jacek Tomków

jacek.tomkow@pg.edu.pl

1 Faculty of Mechanical Engineering, Gdańsk University of Technology, Gabriela Narutowicza 11/12, 80-233 Gdańsk, Poland operational offshore platforms in the Norwegian Continental Shelf and the UK Continental Shelf have exceeded their design life [9]. Engineering is trying to make exploitation time longer, which can reduce the cost of the potential repairs or enable changing the constructions to new ones. This could be done in the stage of design, production, or repair.

A lot of investigations are being carried out on the strengthening, modification, and repair techniques used in offshore constructions. These techniques are classified into five groups: welding, improvement of the weld, clamping, grout filling, and others [10]. Some of them are implemented during the production of the construction as shot peening for treating the multipass welding-inducted residual stresses in offshore wind turbine monopiles [11]. The other welding method used to extend the life of the offshore constructions is welding with the specific sequence [12]. Due to extreme environmental conditions and loading induced upon an offshore construction, the normalized and the thermomechanically treated steels with high yield point are widely used [13]. They allow reducing the weight and size of constructions while maintaining appropriate mechanical properties [14]. The weldability of steels in the air environment is widely investigated. It has been shown that it depends on chemical composition, manufacturing method, and technological, metallurgical, and construction factors, and above all the welding technology [15-17]. Much less frequently mentioned is the subject of steels with yield strength higher than $420 \mathrm{MPa}$ welded directly in the water. 
Table 1 Chemical composition of the investigated steels, wt $\%$

\begin{tabular}{lllllllllllll}
\hline Material & $\mathrm{C}$ & $\mathrm{Si}$ & $\mathrm{Mn}$ & $\mathrm{P}$ & $\mathrm{Cr}$ & $\mathrm{Mo}$ & $\mathrm{Ni}$ & $\mathrm{Al}$ & $\mathrm{Cu}$ & $\mathrm{V}$ & $\mathrm{S}$ & $\mathrm{Ce}$ IIW \\
\hline S460ML & 0.11 & 0.35 & 1.39 & 0.01 & 0.02 & 0.02 & 0.25 & 0.04 & 0.27 & 0.003 & 0.001 & 0.385 \\
S460N & 0.16 & 0.53 & 1.51 & 0.02 & 0.07 & 0.03 & 0.05 & 0.03 & 0.13 & 0.097 & 0.003 & 0.464 \\
\hline
\end{tabular}

The repair technique most often used for offshore constructions is underwater welding, which can improve the quality of joints or repair the gaps in the surfaces. This process is of three main types. The first one is dry welding, in which the welding area and welder are isolated from the environment. This method requires building a special chamber to avoid the surrounding water from contacting the welding zone, which adds to the cost of the process. The pressure inside the chamber could be the same as in the air (isobaric dry welding) or can be due to the depth (hyperbaric dry welding). This method also increases the cost but the quality of the joints could be similar to the joints made in the air $[18,19]$. The second method of underwater welding is welding with a local dry chamber. In this method, the welder is in the water, but the areas of welding and joint are isolated from the environment by a small chamber, in which the welding gas removes the water outside. This phenomenon produces conditions similar to the hyperbaric dry welding but does not require building any expensive chamber $[20,21]$. The last is the most popular and the cheapest method of underwater welding which is known as wet welding. This method also does not require building of any special chambers. During wet welding, the welder and the welding area are in direct contact with the surrounding environment throughout the process. The most popular wet welding processes are flux-cored arc welding (FCAW) [22-26] and welding with the use of covered electrodes (MMA) [27-29].

Water as a welding environment increases the susceptibility of steel to cold cracking [30,31]. Cold cracks can occur in the welds and in the heat-affected zone (HAZ) of the welded joints even $48 \mathrm{~h}$ after welding $[32,33]$. Welding in the water increases the number of cold cracks due to high cooling rate, which makes the HAZ brittle [22, 23, 27, 30]. This can also generate higher residual stresses after welding. The third reason for cold cracking, which cannot be avoided during wet welding in the water, is the high diffusible hydrogen content of deposited metal. The welding conditions have a high influence on the saturation of the metal structure with hydrogen in each environment [34]. It was proved that water generates much more diffusible hydrogen than during air welding [35]. An additional factor increasing the risk of cracking is the local stress concentration due to imperfections resulting from the instability of the welding arc [36-40].

In the present research, the high-strength low-alloy (HSLA) S460ML and S460N steels were selected as study materials. Both of them are characterized by a high susceptibility to cold cracking in wet welding conditions $[27,30]$. The cracks occur in the HAZ of these steels which could be the reason for damage of the construction. The previous investigations showed that the use of temper bead welding (TBW) could reduce the susceptibility to cold cracking the S460ML [30] and S460N steels [31]. However, they were carried out in the bead-on-plate conditions, but not in the real welded joints. In this paper, the influence of the application of the TBW technique in the preparation of dissimilar T-joint fillet welds made in the underwater conditions on the susceptibility to cold cracking was investigated. Welding T-joint was chosen because this type of joint is widely used in thermomechanically treated steels [41] and the fillet welds are most commonly used for underwater welding.

\section{Materials and methods}

For welding, the S460ML and S460N (12 mm thick) steel plates were chosen as base material (BM). The chemical composition of both BMs was analyzed by the emission spectrometry method and is presented in Table 1 . The investigated steels have similar values of yield point (min. $460 \mathrm{MPa}$ ). However, they are characterized by a different carbon equivalent (the absolute difference in $\mathrm{Ce}_{\text {IIW }}$ values of about $0.08 \%$ ). The ISO 2560-A [42]: E $380 \mathrm{R} 11$ rutile electrodes with a diameter of $4.0 \mathrm{~mm}$ were used as a filler material. These electrodes provide good plasticity of the weld, which can minimize the possibility of cold cracking. The chemical composition of filler material is presented in Table 2.

For test three T-joint specimens with fillet welds were prepared. They were made at a depth of $0.2 \mathrm{~m}$ (distance from
Table 2 Chemical composition of the E $380 \mathrm{R} 11$ rutile electrode deposit based on manufacturer's data, wt $\%$

\begin{tabular}{llllllll}
\hline Material & $\mathrm{C}$ & $\mathrm{Si}$ & $\mathrm{Mn}$ & $\mathrm{P}$ & $\mathrm{Cr}$ & $\mathrm{Cu}$ & $\mathrm{S}$ \\
\hline E 38 0 R11 electrodes deposit & 0.07 & 0.44 & 0.55 & 0.01 & 0.04 & 0.05 & 0.001 \\
\hline
\end{tabular}


Fig. 1 Schematic view of T-joints with fillet welds
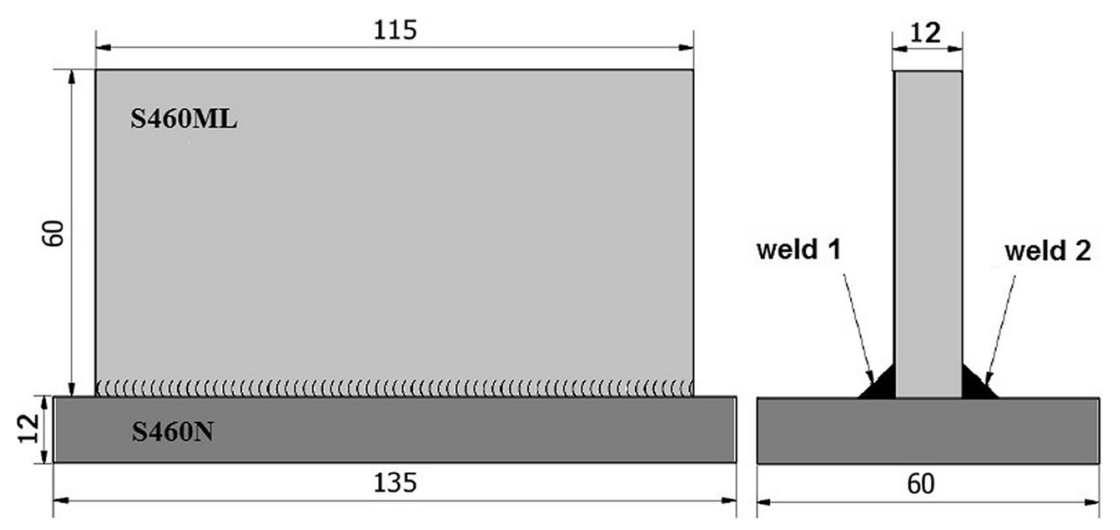

water surface to the upper surface of S460N steel) at a temperature of $20^{\circ} \mathrm{C}$. Plates from S460ML steel had a dimension of $115 \times 60 \mathrm{~mm}$; dimension and plates from the S460N steel had a dimension of $135 \times 60 \mathrm{~mm}$. The schema of T-joint is presented in Fig. 1.

During manufacturing of joints, the basic assumption was to simulate the technological and thermal conditions of repair welding of ribs in a freshwater reservoir. The specimens were tacked under water and were able to deform freely, especially the web (S460ML plate, Fig. 1), simulating, among others, the stiffening of structures, which are used in repairs in wet welding conditions. The dimensions of the specimens were smaller than the elements of structures operated under water, which for this element thickness $(12 \mathrm{~mm})$ worsened the thermal conditions compared to real ones.

One specimen was welded using the traditional technique (one weld). In two others, TBW technique was used. TBW relies on laying the second bead to the bead welded earlier to providing the local heat treatment of weld and HAZ structures occurred during the first welding. Between two welds, $120 \mathrm{~s}$ time was passed. Previous experiments with the investigated steels in the bead-on-plate conditions [30, 31] showed that TBW can be an effective method to improve the weldability of steel in the water, but only in the best range of the overlap values between the subsequent beads. This range was estimated as $75-100 \%$ for S460ML and $66-100 \%$ for S460N [30, $31]$. In accordance with this information, the welds in the two specimens were welded using the TBW technique with a different pitch (percentages of overlap of the second weld bead onto the first weld) to check the influence of TBW on the properties of the T-joint fillet welds.

The welding parameters were chosen in accordance with the previous investigations [30, 31] and are presented in Table 3. Heat input values were calculated without taking into account the thermal efficiency coefficient " $\mathrm{k}$ " in accordance with the requirements of EN 1011-1 standard. The coefficient " $k$ " was omitted because its value is unknown in water environment.

All welded joints were tested by visual testing (VT) and penetrant testing (PT). The aim of VT and PT, besides the assessment of the quality of the prepared joints, was to select appropriate places for cutting. Following VT and PT, the selected cross-sections were tested by macroscopic and microscopic testing. During macroscopic testing, the pitch (percentage overlapping of tempering bead on previously laid bead) was calculated from the prepared photos of cross-sections

Table 3 Welding parameters

\begin{tabular}{|c|c|c|c|c|c|c|c|}
\hline Specimen & Weld & Bead & $\begin{array}{l}\text { Welding } \\
\text { current } \\
\text { I [A] }\end{array}$ & $\begin{array}{l}\text { Arc } \\
\text { voltage } \\
\mathrm{U}[\mathrm{V}]\end{array}$ & $\begin{array}{l}\text { Welding } \\
\text { time } \\
\mathrm{t}[\mathrm{s}]\end{array}$ & $\begin{array}{l}\text { Welding } \\
\text { speed } \\
\text { Vsp }[\mathrm{mm} / \mathrm{s}]\end{array}$ & $\begin{array}{l}\text { Heat input ql } \\
{[\mathrm{kJ} / \mathrm{mm}]}\end{array}$ \\
\hline \multirow[t]{2}{*}{1} & 1 & 1 & 172 & 30.0 & 21.4 & 4.8 & 1.07 \\
\hline & 2 & 1 & 180 & 27.5 & 20.2 & 5.1 & 0.97 \\
\hline \multirow[t]{4}{*}{2} & 1 & 1 & 180 & 26.8 & 20.8 & 5.1 & 0.96 \\
\hline & & 2 & 196 & 26.8 & 18.3 & 5.7 & 0.92 \\
\hline & 2 & 1 & 176 & 28.8 & 17.8 & 5.9 & 0.86 \\
\hline & & 2 & 192 & 31.3 & 20.2 & 5.2 & 1.12 \\
\hline \multirow[t]{4}{*}{3} & 1 & 1 & 180 & 27.0 & 23.5 & 4.6 & 1.06 \\
\hline & & 2 & 200 & 28.0 & 15.6 & 6.9 & 0.81 \\
\hline & 2 & 1 & 176 & 28.5 & 20.9 & 5.2 & 0.97 \\
\hline & & 2 & 192 & 30.8 & 19.5 & 5.5 & 1.07 \\
\hline
\end{tabular}



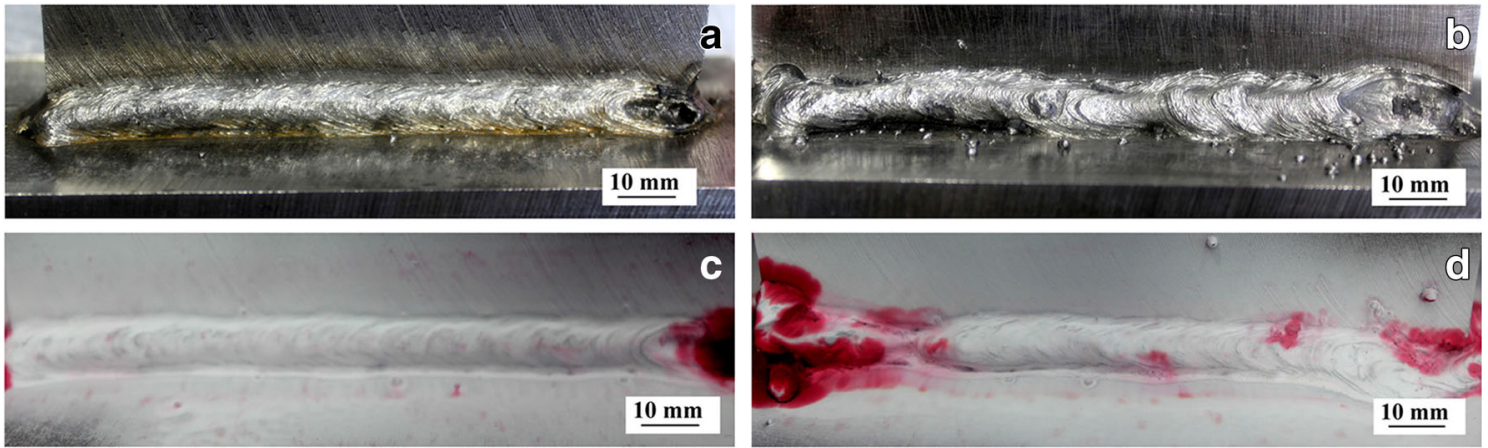

Fig. 2 Exemplary results of the non-destructive tests. a VT, weld 1 from specimen 1; b VT, weld 1 from specimen 3; c PT, weld 2 from specimen 1; and d PT, weld 2 from specimen 2

using the graph. In microscopic testing, the structures in HAZ and weld were observed. After these examinations, hardness (HV10) was measured. The investigated BMs were classified into materials of group 2.2. (S460ML) and 1.3. (S460N) in accordance with the EN ISO 15614-1:2017 [43] standard. For both groups, the maximum hardness of HAZ should not
Fig. 3 Results of the macroscopic testing. a Weld 1 specimen $1-$ without TBW, b weld 2 specimen 1 -without TBW, c weld 1 specimen 2-pitch $0 \%$, d weld 2 specimen 2 - pitch 79\%, e weld 2 specimen 3 - pitch $91 \%$, and $\mathbf{f}$ weld 1 specimen 3-pitch $100 \%$ a

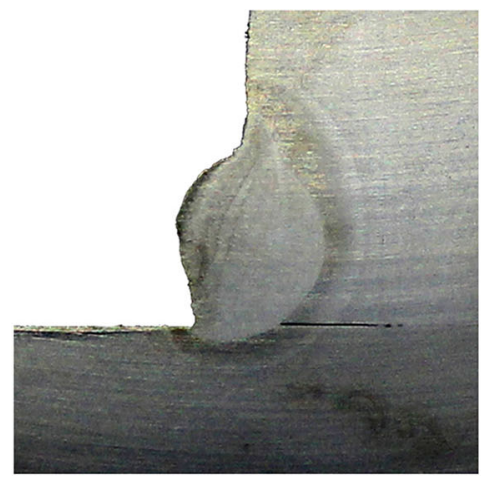

C

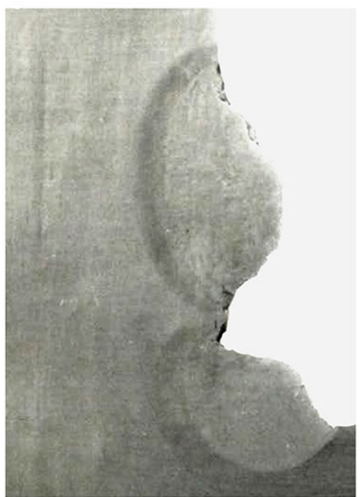

e

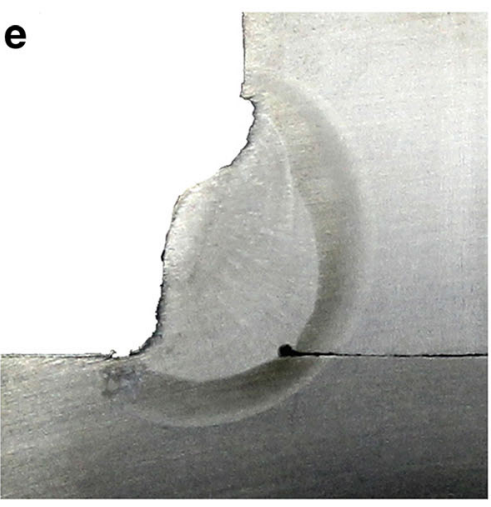

b

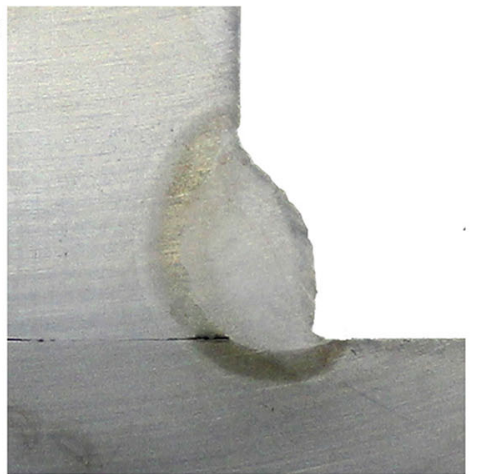

d

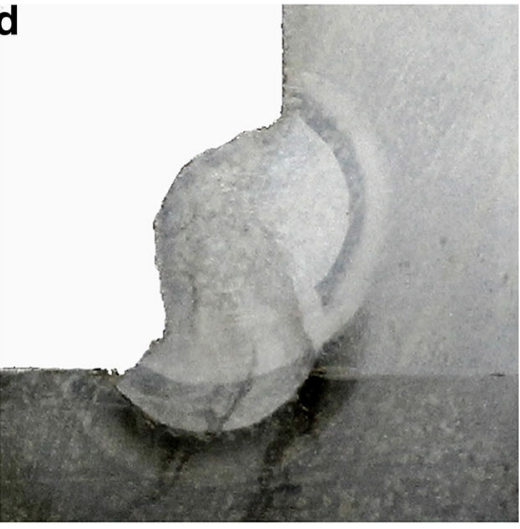

f

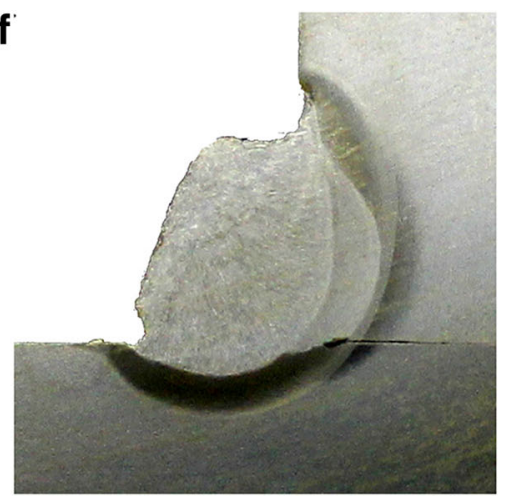



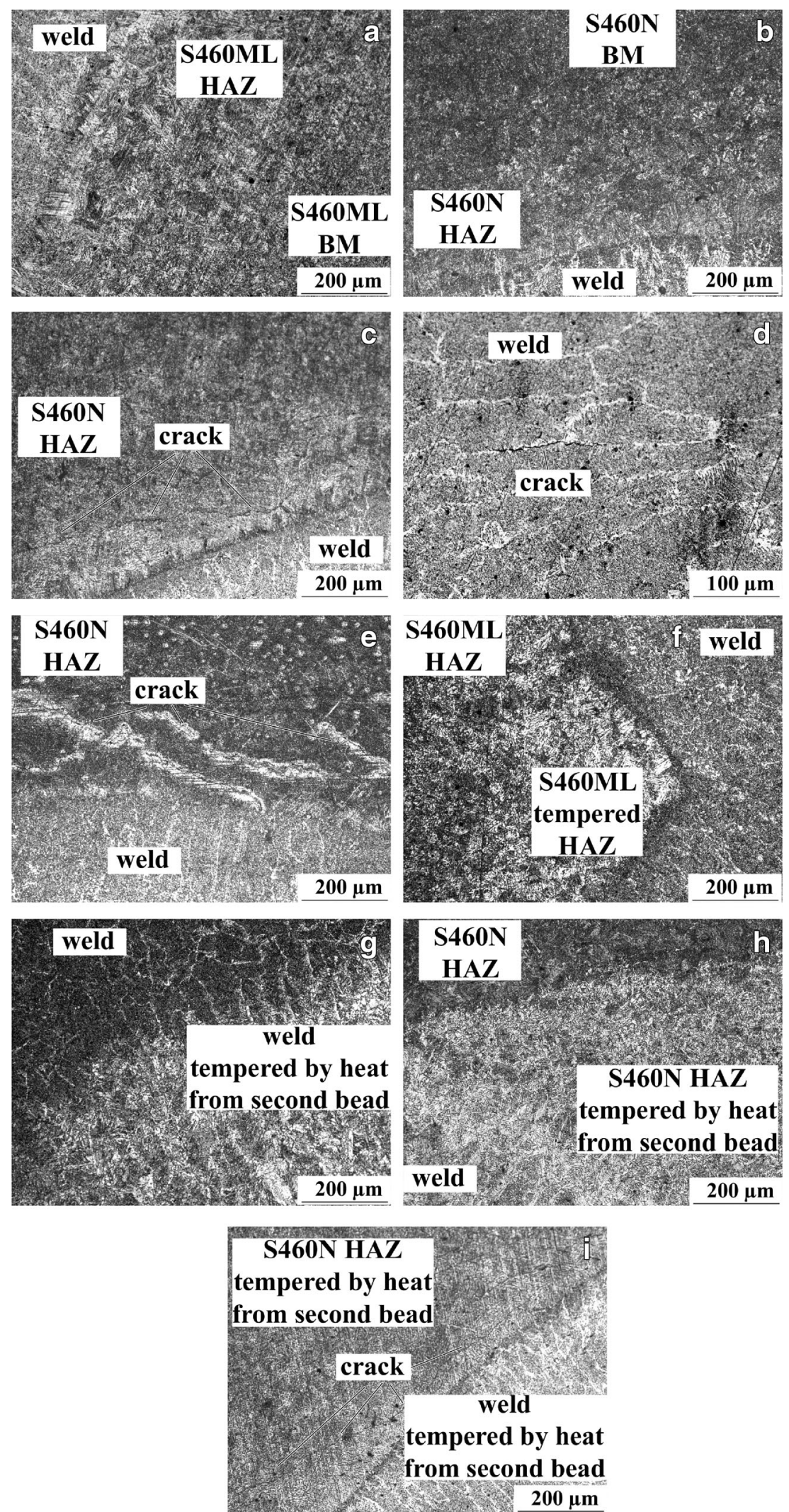

Fig. 4 Results of the microscopic tests. a Structure of S460ML HAZwithout TBW, b structure of S460N HAZ - without TBW, $\mathbf{c}$ cracks in S460N HAZ - without TBW, d cracks in weld material - without TBW, e cracks in S460N HAZ - pitch 0\%, f tempered S460N HAZ - pitch 0\%, g S460ML weld material tempered by heat from second bead, $\mathbf{h}$ tempered S460N HAZ that was affected by heat from second bead, and $\mathbf{i}$ cracks in S460N HAZ - pitch $91 \%$ 
exceed 380 HV10. Hardness measurements together with metallographic tests are a good indicators describing the tendency to cracking.

\section{Results and discussion}

\subsection{Non-destructive testing}

At first, all six welds were visually tested in accordance with the EN ISO 17637:2011 standard [44]. Then, all of them were subjected to PT in accordance with EN ISO 3452-1:2013-08 standard [45]. Non-destructive tests were performed which showed some imperfections in welds prepared using the TBW technique. The most common imperfections were lack of fusion and undercut (Fig. 2b and d). These imperfections resulted from temper beads which were laid only for tempering the previous beads. Because the undercuts are classified as imperfect shape and dimension of weld, and do not affect the changes in the structure and properties of joints, all specimens were subjected to further tests. During testing, spatters was found on the surface of the specimens. In all welds, there were areas without any surface imperfection, which allowed the specimens and preparing cross-sections for further examinations. The exemplary results of the non-destructive tests are presented in Fig. 2.

\subsection{Metallographic testing}

Macro- and microscopic investigations were performed in accordance with EN ISO 17639:2013 standard [46]. After cutting, all the cross-sections were ground, polished, and etched with Nital (4\%). The main aim of the macroscopic testing was to calculate the pitch in specimens 2 and 3. During macroscopic observations, the imperfection was seen as gas pores in both welds from specimen 1 , weld 1 from specimen 2 , and weld 2 from specimen 3 . All these imperfections were located near the point of contact between the BMs. The used TBW technique did not affect their formation - the second weld did not cover these places. The results of the macroscopic testing are presented in Fig. 3.

After macroscopic tests, the microscopic investigations were performed. The weld metal structures in specimen 1 were built of dendrites. In the specimen 1 -welded without TBW technique, brittle structure such as low-carbon martensite was found in the HAZ of both steels in each welded joint. Near the fusion line the Widmannstätten structure was observed (Fig. 4a and b). In addition, in the HAZ of the S460N steel, cracks were found in weld 2, which was welded with a lower heat input (Fig. 4c). These cracks started in HAZ and propagated along approximately $80 \%$ of the length of the fusion line in the S460N steel. Cracks were also found in the weld material of the specimens in which the TBW technique was not applied (Fig. 4d). In the case of specimens made using TBW, there was no crack in the weld materials. In weld 1 specimen 2 , where the pitch was $0 \%$, the HAZ in S460N was not changed and still presented brittle structures with cracks (Fig. 4e). The pitch was $0 \%$; however, the HAZ from tempering bead refined and tempered the coarse-grained zone of the first bead in the S460ML steel (Fig. 4f). In the specimens with the pitch in the range of $79-100 \%$, the tempering effect was observed in the HAZ of both the investigated materials. With an increase in the pitch, there was a decrease of grain size, which was expected in accordance with previous works [30, 31]. In the places where the HAZ of the second bead tempering the weld from the first bead, there was a partial disappearance of the structure of the dendritic base bead and the formation of a ferritic fine-grained structure (Fig. 4g). The structures in the area where the HAZ from tempering bead overlapped the HAZ of the first bead in both steels were characterized by the refined and tempered coarse-grained zone (Fig. 4h). The cracks in the HAZ of the BMs were found only in weld 2 in specimen 3 in the S460N steel (Fig. 4i). In the previous investigations [27, 30 ], it was found that TBW could not repair the microcracks that formed during the welding of the first bead. However, TBW could help to avoid cold cracking that might occur after welding [47, 49].

\subsection{Hardness measurements}

The hardness was measured in BM, in each HAZ, and in the weld material for each investigated weld of a specimen. The schema of distribution of hardness points is presented in Fig. 5.

The measurement showed that the S460N steel is characterized by a higher Vickers HV10 hardness than S460ML, as can be observed in the measurements obtained for each specimen. In the specimens in which TBW technique was not applied, the hardness in the HAZ of both the used steels was the highest and exceeded the level of 380 HV10 assumed by

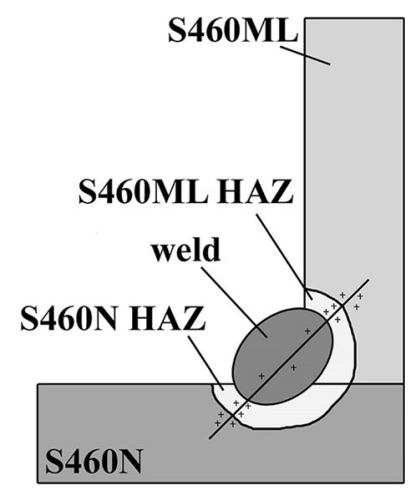

Fig. 5 Hardness point distribution for specimen welded without and with TBW technique 
Table 4 Hardness measurement results

\begin{tabular}{|c|c|c|c|c|c|c|c|c|c|c|c|c|c|c|c|}
\hline \multirow{2}{*}{$\begin{array}{l}\text { Specimen } \\
\text { Without TBW } 1\end{array}$} & \multicolumn{3}{|c|}{$\mathrm{S} 460 \mathrm{~N}$} & \multicolumn{3}{|c|}{ S460N HAZ } & \multicolumn{3}{|c|}{ Weld } & \multicolumn{3}{|c|}{ S460ML HAZ } & \multicolumn{3}{|c|}{ S460ML } \\
\hline & 228 & 207 & 208 & 425 & 473 & 488 & 325 & 319 & 299 & 421 & 437 & 483 & 202 & 192 & 212 \\
\hline Without TBW2 & 221 & 233 & 219 & 498 & 503 & 446 & 306 & 297 & 309 & 390 & 405 & 429 & 182 & 181 & 195 \\
\hline $0 \%$ & 222 & 218 & 222 & 383 & 432 & 419 & 304 & 276 & 262 & 314 & 304 & 324 & 199 & 199 & 195 \\
\hline $79 \%$ & 216 & 210 & 228 & 390 & 417 & 483 & 276 & 272 & 281 & 314 & 309 & 302 & 195 & 193 & 199 \\
\hline $91 \%$ & 207 & 225 & 219 & 397 & 398 & 384 & 267 & 248 & 255 & 378 & 360 & 402 & 187 & 188 & 197 \\
\hline $100 \%$ & 233 & 218 & 215 & 395 & 370 & 382 & 266 & 270 & 276 & 314 & 341 & 349 & 207 & 197 & 191 \\
\hline
\end{tabular}

EN ISO 15614-1:2017 standard for used steels. It was also observed that the hardness of S460N HAZ was higher than that of S460ML HAZ. In the specimen with the $0 \%$ pitch, the heat from the second bead, which was laid in S460N BM, affected the hardness of both steels. Second, HAZ was overlapping first in S460ML, and the hardness in this area decreased by $80-100$ HV10 in comparison with the specimens welded without the TBW technique. In S460N HAZ, the hardness decreased by $40-80 \mathrm{HV} 10$. In the next specimens, it was observed that if the pitch between two beads increased, the hardness in HAZ and weld material decreased. The best results for the investigated BMs were observed in the specimens with $100 \%$ pitch. The hardness measurements showed that the TBW technique allowed to reduce the hardness HV10 values of joints made in the water to the values lower than in specimens welded in the air [27]. Similar results were observed for welding of HSLA steel butt joints [49]. The reduction of hardness limits one of the factors adding to the initiation of cold cracks, which contributes to a reduction of cracking susceptibility.

The values of hardness in each point are presented in Table 4. The phrase "without TBW" means specimen welded without additional (tempering) bead. The specimen with "0\%" pitch was welded with tempering bead. However, in the area of cutting specimen for metallographic testing, the second bead did not lay on the first one (Fig. 3c), but the heat from the second bead affects the previous laid stitch. The hardness distributions for each specimens are presented in Fig. 6.

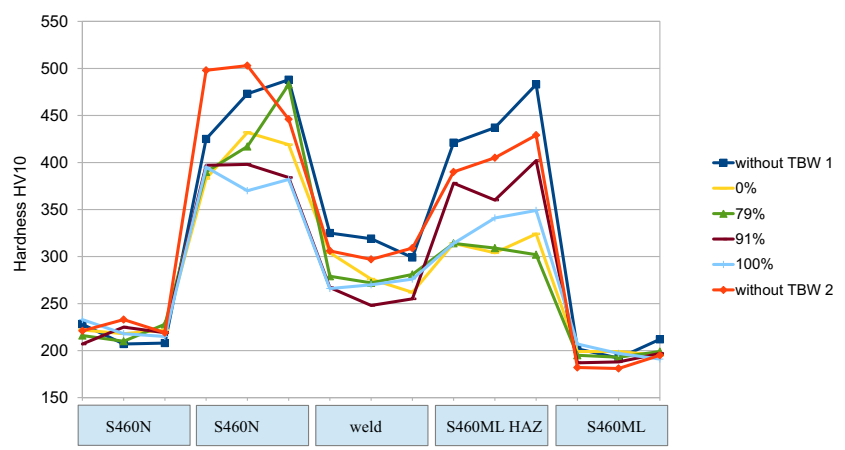

Fig. 6 Hardness HV10 distribution for each specimen

\section{Conclusions}

The results of the experiments conducted in the present study showed that both materials, S460N and S460ML, were characterized by high susceptibility to cold cracking in the HAZ, as was found in the specimens made without the TBW technique. The use of this technique allowed reducing the number of cracks and decreasing the hardness in the HAZ of both steels. The results proved that the $\mathrm{Ce}_{\text {IIW }}$ values cannot be considered as good weldability indicator for wet welding in water environment. In previous researches [31, 32], TBW was used in pad welding conditions. Bead-on plate welding is a relatively simple process which is carried out only with one base material. During T-joint fillet welding, the thermal severity is more complicated, which can result in formation of different brittle structures. The experiments presented in this paper confirmed the effectiveness of used TBW technique in the conditions of preparing welded joints. It is also confirmed that this technique can be used in preparing dissimilar joints. The performed conclusions can be used during repairing of offshore constructions in the cases where used materials are characterized by susceptibility to cold cracking.

The conclusions drawn based on results of the conducted experiments are:

1. The TBW technique was effective in improving the quality of the dissimilar T-joint fillet welds of the S460 class steel made in the water by wet welding method.

2. The used technique reduced the number of cracks in the HAZ of both steel; however, it was ineffective in repairing the cracks that occurred while the first bead was welded.

3. TBW allowed changing the structures of dissimilar welding of T-joints. The grain size was decreased and the brittle structures were tempered, which improved the weldability of steel (expressed by HAZ hardness decreasing) and the quality of the prepared joints (expressed by number of crack in HAZ). The changes were observed in both of the welded steels.

4. The investigated technique reduced the hardness in the HAZ of the S460N steel by $40-50 \mathrm{HV} 10$ and in 
S460ML by $80-100$ HV10. When the pitch between two beads increased, the hardness decreased. The beneficial effect of the application of the TBW technique was more significant in steel with a lower $\mathrm{Ce}_{\text {IIW value }}$ (S460ML).

Open Access This article is licensed under a Creative Commons Attribution 4.0 International License, which permits use, sharing, adaptation, distribution and reproduction in any medium or format, as long as you give appropriate credit to the original author(s) and the source, provide a link to the Creative Commons licence, and indicate if changes were made. The images or other third party material in this article are included in the article's Creative Commons licence, unless indicated otherwise in a credit line to the material. If material is not included in the article's Creative Commons licence and your intended use is not permitted by statutory regulation or exceeds the permitted use, you will need to obtain permission directly from the copyright holder. To view a copy of this licence, visit http://creativecommons.org/licenses/by/4.0/.

\section{References}

1. Dehghani A, Aslani F (2019) A review on defects in steel offshore structures and developed strengthening techniques. Structures 20: 635-657. https://doi.org/10.1016/j.istruc.2019.06.002

2. Wei X, Wen Z, Xiao L, Wu C (2018) Review of fatigue assessment approaches for tubular joints in CFTS trusses. Int J Fatigue 113:4353. https://doi.org/10.1016/j.ijfatigue.2018.04.007

3. Price SJ, Figueira RB (2017) Corrosion protection systems and fatigue corrosion in offshore wind structures: current status and future perspectives. Coatings 7(2):25. https://doi.org/10.3390/ coatings 7020025

4. den Besten H (2018) Fatigue criteria classification, modeling developments and trends for welded joints in marine structures. Ships Offshore Struc 13(8):787-808. https://doi.org/10.1080/17445302. 2018.1463609

5. Kandukuri ST, Robbersmyr KG, Karimi HR (2016) Towards farmlevel health management of offshore wind farms for maintenance improvements. Int J Adv Manuf Technol 83:1557. https://doi.org/ 10.1007/s00170-015-7616-y

6. M-s P, Koo W, Kawano K (2011) Dynamic response analysis of an offshore platform due to seismic motions. Eng Struc 33(5):16071616. https://doi.org/10.1016/j.engstruct.2011.01.030

7. Yang H, Zhu Y, Lu Q, Zhang J (2015) Dynamic reliability based design optimisation of the tripod sub-structure of offshore wind turbines. Renew Energy 78:16-25. https://doi.org/10.1016/j. renene.2014.12.061

8. Soman R, Mieloszyk M, Ostachowicz W (2018) A two-step damage assessment method based on frequency spectrum change in a scaled wind turbine tripod with strain rosettes. Mar Struc 61:419422. https://doi.org/10.1016/j.marstruc.2018.06.013

9. Aeran A, Siriwardane SC, Mikkelsen O, Langen I (2017) A framework to assess structural integrity of ageing offshore jacket structures for life extension. Mar Struc 56:237-259. https://doi.org/10. 1016/j.marstruc.2017.08.002

10. Samarakoon SMK, Ratnayake RMC (2015) Strengthening, modification and repair techniques' prioritization for structural integrity control of ageing offshore structures. Reliab Eng Syst Saf 135:1526. https://doi.org/10.1016/j.ress.2014.10.023

11. Khajeian A, Mahmoudi AH, Mehmanparast A (2019) Shot peening effects on residual stresses redistribution of offshore wind monopile multi-pass weldments. Mar Struct 62:106-120. https://doi.org/10. 1016/j.marstruc.2019.03.006
12. Bai R, Guo Z, Tian C, Lei Z, Yan C, Tao W (2018) Investigation on welding sequence of I-beam by hybrid inversion. Mar Struc 62:2339. https://doi.org/10.1016/j.marstruc.2018.07.002

13. Igwemezie V, Mehmenparast A, Kolios A (2019) Current trend in offshore wind energy sector and material requirements for fatigue resistance improvement in large wind turbine support structures - a review. Renew Sust Energ Rev 101:181-196. https://doi.org/10. 1016/j.rser.2018.11.002

14. Kurian T, Rajiv S, Subroto Kumar B (2018) A computer simulation model for thermal forming of ship and offshore constructions. J Ship Prod Des 34(4):279-309. https://doi.org/10.5957/JSPD. 160030

15. Skowrońska B, Chmielewski T, Golański D, Szulc J (2020) Weldability of S700MC steel welded with the hybrid plasma+ MAG method. Manufacturing Rev 7:4. https://doi.org/10.1051/ mfreview/2020001

16. Kurc-Lisiecka A, Lisiecki A (2019) Hybrid laser-GMA welding of high-strength steel grades. Mater Perform Charact 8(4):614-625. https://doi.org/10.1520/MPC20190070

17. Rogalski G, Świerczyńska A, Landowski M, Fydrych D (2020) Mechanical and microstructural characterization of TIG welded dissimilar joints between 304L austenitic stainless steel and incoloy 800HT nickel alloy. Metals 10(5):559. https://doi.org/10.3390/ met10050559

18. Hu Y, Shi Y, Sun K, Shen X, Wang Z (2018) Microstructure and mechanical properties of underwater hyperbaric FCA-welded duplex stainless steel joints. J Mater Process Technol 261:31-38. https://doi.org/10.1016/j.jmatprotec.2018.05.027

19. Hu Y, Shi Y, Shen X, Wang Z (2017) Microstructure, pitting resistance and impact toughness of duplex stainless steel underwater dry hyperbaric flux-cored arc welds. Materials 10:1443. https://doi.org/ 10.3390/ma10121443

20. Han L, Wu X, Chen G, Wang Z, Fan W (2019) Local dry underwater welding of 304 stainless steel based on a microdrain cover. J Mater Process Technol 268:47-53. https://doi.org/10.1016/j. jmatprotec.2018.12.029

21. Shi Y, Sun K, Cui S, Zeng M, Yi J, Shen X, Yi Y (2018) Microstructure evolution and mechanical properties of underwater dry and local dry cavity welded joints of $690 \mathrm{MPa}$ grade high strength steel. Materials 11(1):167. https://doi.org/10.3390/ ma11010167

22. Chen H, Guo N, Xu K, Liu C, Wang G (2020) Investigating the advantages of ultrasonic-assisted welding technique applied in underwater wet welding by in-situ X-ray imaging method. Materials 16(6):1442. https://doi.org/10.3390/ma13061442

23. Chen B, Tan C, Feng J (2016) A study on the arc characteristics of underwater wet welding process. Int J Adv Manuf Technol 86:557564. https://doi.org/10.1007/s00170-015-8159-y

24. Wang J, Sun Q, Zhang T, Tao X, Jin P, Feng J (2019) Arc stability indexes evaluation of ultrasonic wave-assist underwater FCAW using electrical signal analysis. Int J Adv Manuf Technol 103: 2593. https://doi.org/10.1007/s00170-019-03463-1

25. Xing C, Jia C, Han Y, Donh S, Yang J, Wu C (2020) Numerical analysis of the metal transfer and welding arc behaviors in underwater flux-cored arc welding. Int J Heat Mass Transf 152:119570. https://doi.org/10.1016/j.ijheatmasstransfer.2020.119570

26. Wei P, Li H, Liu J, Li S, Zhang Y, Zhu Y, Lei Y (2020) The effect of water environment on microstructural characteristics, compositional heterogeneity and microhardness distribution of $16 \mathrm{Mn} / 304 \mathrm{~L}$ dissimilar welded joints. J Manuf Process 56(A):417-427. https:// doi.org/10.1016/j.jmapro.2020.05.006

27. Tomków J, Łabanowski J, Fydrych D, Rogalski G (2018) Cold cracking of $S 460 \mathrm{~N}$ steel in water environment. Pol Marit Res 25(3):131-136. https://doi.org/10.2478/pomr-2018-0104

28. Tomków J, Czupryński A, Fydrych D (2020) The abrasive wear resistance of coatings manufactured on high-strength low-alloy 
(HSLA) offshore steel in wet welding conditions. Coatings 10(3): 219. https://doi.org/10.3390/coatings10030219

29. Yohanes P, Nurul M, Triyono M (2018) Effect of water depth on the microstructure and mechanical properties of SS400 steel in underwater welding. Key Eng Mater 772:128-132. https://doi.org/10. 4028/www.scientific.net/KEM.772.128

30. Tomków J, Rogalski G, Fydrych D, Łabanowski J (2018) Advantages of the application of temper bead welding technique during wet welding. Materials 12(6):915. https://doi.org/10.3390/ ma12060915

31. Tomków J, Fydrych D, Rogalski G, Łabanowski J (2018) Temper bead welding of S460N steel in wet welding conditions. Adv Mater Sci 18(3):5-14. https://doi.org/10.1515/adms-2017-0036

32. Guo W, Li L (2016) Laser welding of high strength steels (S690 and S700) with medium thickness. J Laser Appl 28:022426. https://doi. org/10.2351/1.4944100

33. Hanzaei AT, Marashi S, Ranjabarnodeh E (2018) The effect of hydrogen content and welding conditions on the hydrogen induced cracking of the API X70 steel weld. Int J Hydrogen Energy 43(19): 9399-9407. https://doi.org/10.1016/j.ijhydene.2018.03.216

34. Świerczyńska A, Fydrych D, Łabanowski J (2012) The effect of welding conditions on diffusible hydrogen content in deposited metal. Solid State Phenom 183:193-200. https://doi.org/10.4028/ www.scientific.net/SSP.183.193

35. Tomków J, Fydrych D, Rogalski G, Łabanowski J (2019) Effect of the welding environment and storage time of electrodes on the diffusible hydrogen content in deposited metal. Rev Metall 55(1): e140. https://doi.org/10.3989/revmetalm.140

36. Jia C, Wu J, Han Y, Zhang Y, Yang Q, Wu C (2020) Underwater pulse-current FCAW - part 1: waveform and process features. Weld J 99:135-145. https://doi.org/10.29391/2020.99.013

37. Yang Q, Han Y, Jia C, Dong S, Wu C (2020) Visual investigation on the arc burning behaviors and features in underwater wet FCAW. J Offshore Mech Arct Eng 142(2):041401. https://doi. org/10.1115/1.4045914

38. Xu C, Guo N, Zhang X, Chen H, Fu Y, Zhou L (2020) Internal characteristic of droplet and its influence on the underwater wet welding process stability. J Mater Process Technol 280:116593. https://doi.org/10.1016/j.jmatprotec.2020.116593
39. Wang J, Sun Q, Hou S, Zhang T, Jin P, Feng J (2019) Dynamic control of current voltage waveforms and droplet transfer for ultrasonic-wave-assisted underwater wet welding. Mater Des 181: 108051. https://doi.org/10.1016/j.matdes.2019.108051

40. Wang J, Sun Q, Teng J, Feng J (2019) Bubble evolution in ultrasonic wave-assisted underwater wet FCAW. Weld J 98(5):150 163. https://doi.org/10.29391/2019.98.012

41. Kik T (2020) Computational techniques in numerical simulations of arc and laser welding processes. Materials 13(3):608. https://doi. org $/ 10.3390 / \mathrm{ma} 13030608$

42. ISO 2560-A Classification of coated rod electrodes for arc welding of unalloyed steel and fine-grained steel.

43. EN ISO 15614-1:2017 Specification and qualification of welding procedures for metallic materials — welding procedure test — part 1: arc and gas welding of steels and arc welding of nickel and nickel alloys.

44. EN ISO 17637:2017 Non-destructive testing of welds-visual testing of fusion-welded joints.

45. EN ISO 3452-1:2013-08 Non-destructive testing - penetrant testing - part 1: general principles.

46. EN ISO 17639:2013-12 Destructive tests on welds in metallic materials - macroscopic and microscopic examination of welds.

47. Chen H, Guo N, Zhang X, Cheng Q, Zhou L, Wang G (2020) Effect of water flow on the microstructure, mechanical performance, and cracking susceptibility of underwater Q235 and E40 steel. J Mater Process Technol 277:116435. https://doi.org/10.1016/j.matprotec. 2019.116435

48. Tomków J, Fydrych D, Wilk K (2020) Effect of electrode waterproof coating on quality of underwater wet welded joints. Materials 13(13):2947. https://doi.org/10.3390/ma13132947

49. Tomków J, Janeczek A (2020) Underwater in situ local heat treatment by additional stitches for improving the weldability of steel. Appl Sci 10(5):1823. https://doi.org/10.3390/app10051823

Publisher's note Springer Nature remains neutral with regard to jurisdictional claims in published maps and institutional affiliations. 